\title{
Parent Involvement in Child Education as a Correlate of Academic Performance: Analyzing Denominational Secondary Schools in Uganda
}

\author{
Denis Sekiwu \\ Kabale University, Kabale, Uganda \\ Victoria Tamale Kaggwa \\ Makerere University, Kampala, Uganda
}

\begin{abstract}
The study examined how parent involvement in child education influences students' academic performance in secondary schools in Tororo district, Uganda, with parents' socio-economic status as the control variable. The comparative research design was employed with a sample of 360 students from eight denominational schools. The Parent Involvement Guide (PIG) was used to collect data and quantitative data analysis indicated that parent involvement in child education positively influences students' academic performance. There are differences in students' academic performance among different denominational schools with Moslem schools performing least with low parent involvement in child education, and Catholic schools performing highest with high parent involvement in child education. Parent involvement in child education is higher at home than in the school. Thus, parents are encouraged to get involved in child education and there is need to encourage schools to focus their values-orientations on increasing students' academic performance.
\end{abstract}

Key words: Parent Involvement, Child Education, Academic Performance, Secondary School Students, Education in Uganda

\section{INTRODUCTION}

Worldwide, education is an economic investment which contributes to national development (Nsubuga, 2008; Fajoju, Oyaziwo Aluede \& Ojugo, 2016). The demands of today's highly competitive society are provoking schools to invest in child education (Mugagga, Sekiwu \& Kiggundu, 2016). In any economically competitive society, educational attainment is the most reliable passport to obtaining employment, earning reasonably, as well as partaking in public decision-making and social development (Ahuja, 2005). In other words, education attainment is strongly correlated with positive life and citizenship (Reigier, 2016; Eccles \& Harold, 2004; Thiele, Singleton, Pope, \& Stanistreet, 2016; Breen \& Jonsson, 2005).

Because of the value of education, schools tend to encourage active parental involvement in boosting the educational outcomes of school children (Mau, 1997; Shanham \& Walberg, 1985). For example, Bempechat (1992) provides that parents' behaviour with their children, such as stimulation, consistency, moderation and responsiveness, influence children's cognitive and social development patterns. Parental involvement, according to (Hara, 1998; Jeynes, 2007), is the primary vehicle by which to improve child education. Therefore, children's education is not expected to be left in the hands of school administrators and teachers alone but also in the hands of every one, most especially the parents and the child's immediate family members (Fajoju, Oyaziwo Aluede \& Ojugo, 2016; Hill \& Taylor, 2004). 
There is substantial literature (Fan, 2001; Epstein, Sanders, Simon, Salinas, Jansorn \& Voorhis, 2002) observing that high school students with parents who are highly involved in their education have higher levels of academic achievement, on average, than those with less engaged parents. This is because highly involved parents understand the education system and the difficulties schools face and can easily manipulate scholarship trends and as well as students' expectations (Allardice \& Blicharski, 2000). The same parents are also prepared to tender their valuable support which schools cannot afford to underestimate (Hill \& Taylor, 2004), they can also tap into rich information sources and expertise that can help build schools and communities (Smith \& Liebenberg, 2003), they can promote quality education (Elbaum, 2014) and foster improved student learning, attendance and behaviour, regardless of the student's social or cultural background (Christenson \& Reschly, 2010).

The role of parents in child education is therefore historical. Families and schools have worked together since the beginning of formalized schooling (Epstein \& Sanders, 2002). Families have maintained a high degree of control over schooling, the hiring of teachers and responsible for preparing their children with the necessary skills in the early years of childhood growth and development (Hill \& Taylor, 2004). But today, in the context of greater accountability and demands for children's achievement, schools and families have formed partnerships and share the responsibility for children's education. This further implies that parental involvement is associated with early home and school success, including academic and language skills as well as social competence development (Grolnick \& Slowaczek, 1994; Hill, 2001).

But the fostering of parental involvement in child education is one of the global strategies with theoretical underpinnings in democratic education governance (Jeynes, 2005). The global school is exponentially shifting away from traditionally conformist leadership practice where teachers were the "I know it All" to more democratic and collegial participation requiring collective education responsibility in child education matters (Mncube, 2003). The democratic participatory view insinuates that decisions regarding child education require more consultation, collaboration and collective participation of stakeholders either at home or in school (Nkata, 2003; Sekiwu, 2015; Sithole, 1998). Parent involvement in child education, therefore, encourages parent-school dialoguing, sustains mutual trust and respect, as well as promoting shared educational responsibility (Williams, 2015; Mabovula, 2008). Parental involvement in child education is also important because parents are the first educators of their children in the home, but continuing to influence their children's learning and development during the school years and long afterwards (Njoroge \& Bennaars, 2000; Ssekamwa, 2000), which is why schools need to recognize the primary role of the parent in education.

However, in Uganda's education context, for parents to bear fruitful involvement in child education, children must academically perform (Nsubuga, 2008). Academic performance that is centered on the examination is the most significant measure of an enabling child education philosophy as stipulated by the Castle Report of 1963 which secularized formal education in Uganda. Therefore, this study examines parental involvement in child education and its influence on children's academic performance. The study is situated in four denominational Secondary Schools in Kabale District.

The problem examined in this study is that despite the global importance of parental involvement in child education (Easton, 2010), however a substantial number of Ugandan parents are rarely involved in their children's academic performance. For example, a Twaweza study (2014) indicates that 43\% of parents never check their children's homework, and 28\% check homework only once a week. Again, only $12 \%$ of the parents endeavor to check 
homework daily while $29 \%$ reported checking homework a few times per month. On a whole, only $48 \%$ of the parents took the initiative to check their children's learning at school (Twaweza, 2014). Having indicated low parent involvement in child education, therefore the research gap is first to establish the extent to which parent involvement in child education would significantly influence academic performance in secondary schools in Uganda with specific reference to Tororo district. To address this problematic, the researchers examined the following specific objectives as drawn from the Conceptual diagram (Figure 1): 1) To compare students' academic performance across eight denominational Schools, 2) To assess the level of parent involvement in child education at home and in school, and 3) To examine the relationship between parent involvement in child education and students' academic performance bearing in mind parents' socio-economic status.

Figure 1: Conceptualizing The Study

Independent Variable

\begin{tabular}{l} 
Parent involvement in Child \\
\hline Education \\
\hline Parent Involvement at Home \\
- Homework \\
- Academic Guidance \\
- Acanancing Education \\
Parent Involvement at School \\
- School Participatory Roles \\
(Meetings, Communication with \\
Teachers) \\
Academic Leadership
\end{tabular}

Dependent Variable

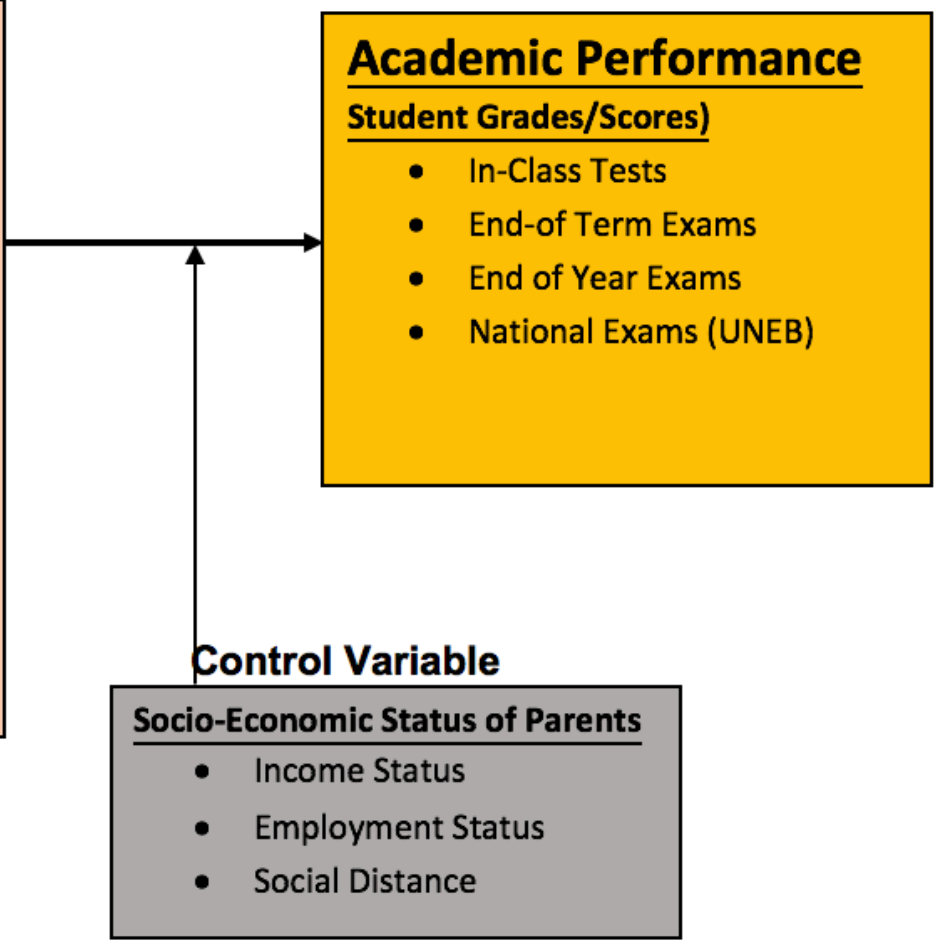

Source: Adopted and Modified from Smith \& Liebenberg (2003) as well as Spera (2006)

\section{PREVIOUS STUDIES ON PARENTAL INVOLVEMENT IN CHILD EDUCATION AND ACADEMIC PERFORMANCE}

The subject of parental involvement in child education and its implications for academic performance has attracted several scholarly debates (Bempechat, 1992; Hill \& Taylor, 2004; Jeynes, 2007 \& 2012; Fajoju et al., 2016) to which this present study builds. Some of the debate espouses that parents can participate in child education right from home by providing encouragement, arranging for appropriate study time and space, modelling desired behaviour (such as reading for pleasure), monitoring homework and actively tutoring their children (Fehrmann, Keith \& Reimers, 1987). There is another debate looking at parental involvement at school like attending school functions and membership to Parent-Teacher Association/Conferences (Rockwell, Andre \& Hawley, 2008; Fajoju et al., 2016). However, for all these studies, the location of the study plays a significant part in determining the direction of the findings. 
For example, a study by Jeynes (2005) uses a weighted composite model to provide that parents attending school functions, communicating with students, and parents checking homework yield a positive effect on academic achievement. On the contrary, Moles' study observes that the socio-economic status of parents yield a negative effect on students' academic achievement because it is related to availability of household income (Moles, 2002), the social distance hypothesis (Eccles \& Harold, 1996), parental intellectual ability to handle more challenging high school academic work (Epstein \& Sanders, 2002), and social capital by increasing parents' skills and information to better equip them to assist their children in academic work (Lareau, 1996; McNeal, 1999).

For the two studies, Jeynes and Moles, findings are rather contradictory because these researchers are placed in different geographical cultures in USA and Europe respectively. This implies that a study cannot easily be generalized to different global regions like Uganda, which would then necessitate a new study of the kind on Uganda in order to predict the direction of the relationship. Even McNeal (1999), earlier on, challenges the above findings by Moles (2002) when he notes that it is not always the case that socio-economic status of parents is negatively related to their involvement patterns and students' academic achievement. There many instances where wealthy families never participate in their children's education because many are too busy to engage in child work. In the same way, not all intellectually able parents have the ability to handle more challenging academic work because the contextual participation levels may differ.

It is further noted that Jeynes' (2005) study is culturally limited to Afro-American students, while that of Desimone (1999), with contradictory findings, looks at racial variables such as Whites and Hispanics. This shows one that with the change in the geographical locale for the study, findings are likely to differ. Similarly, Grolnick and Slowaczek (1994) put their unit of analysis to comparing $8^{\text {th }}$ graders and middle high school sophomores and find out that there is a positive relationship between parental involvement in child education and academic performance. Still this denotes that studies are replicated in varied ways which variations may tend to breed variations in research outcomes. More still, studies by Pelco, Jacobson, Ries, and Melka (2000) focus on homework and parent involvement variables. They found out that high school students spent more time on homework if their parents were more involved. But Steinberg, Lamborn, Dornbusch and Darling (1992) analyze involvement differentiation on the basis of parenting style for adolescents (14-18-year olds). They argue that there is parental involvement success in an authoritative home environment than in a laissez faire family structure. This implies that differences in variables of focus is likely to bring about differentiation in parent involvement and influence on academic performance.

But Joyce Epstein, a leading guru in advising schools to seek parent partnerships in education points her argument on how to nurture a supportive home-school environment as the basis for positive parental involvement and students' academic performance (Epstein, 1986). She tries to assess six parental involvement composites in order to create a more generalizable study, and these are parenting, communicating for effective home-school interactions, volunteering to involve parents at the school, learning at home to provide continued educational activities at home, curriculum decision making and collaborating, which involvement programmes are believed to create a positive association with students' academic achievement (Epstein \& Sanders, 2002; Hill \& Craft, 2003). Although many educators and sociologists have argued that in modern society Epstein's involvement criteria strongly works to build parent-school partnerships in child education (Ferrara, 2009; Gibson \& Jefferson, 2006) that could be globally encompassing, however they tend to ignore conditions where single parenting, migrant labour conditions, and where the white-collar job challenge is a great hindrance to pursuing Epstein's 
involvement criteria in a developing world context (Sy, 2006). Still, Epstein's study is geographically limited to some extent, requiring another study of the kind for Uganda as a developing country context.

Because of the continued variations in results on the subject as indicated by global scholarship, Christenson and Reschly (2010), as well as Henderson and Mapp (2017) would then ask themselves the question "what types of parent involvement supportive programmes would help student achievement the most?" Their hope is to lock out this huge disparity equation and, in their debate, they come up with programmes such as voluntary expressions of mother and father participation. They argue that is possible to teach fathers and mothers how to become more fully engaged in their children's education (Epstein, 2001; Henderson \& Mapp, 2002) which perspective is founded in the Social Learning Theory (SLT) or Behaviouralist Theory. The debate continues to elaborate that when schools teach parents how to become involved and how to effectively motivate parents, it is a critical parental involvement programme which is likely to influence their children's academic performance in more comparative terms than what the likes of Epstein, Desimone, Moles and Jeynes suggested earlier. However, Christenson and Reschly (2010), as well as Henderson et al (2017) fail to give a practical approach on how fathers and mothers would get involved so as to unpack their parental involvement programme. Instead, Hughes and Black (2002), as well as McGhee and Waterhouse (2002) fills in this gap by suggesting voluntary supports such as parental expressions of love, selfdiscipline and loyalty. Still, the contradictions and counter debates emerging from different scholars militates the ethos that there is no single study that can be generalized to different global conditions. It is rather better for new research to be identified for different geographical differentials and different variables of relevance, hence a study of this kind.

Fan (2001) identified four dimensions of parental involvement (educational aspirations, parent-child communication, contact with the school and volunteering) while Sui-Chu \& Willms (1996) valorizes involvement composites such as home discussion, home supervision, school communication, school participation, intellectual engagements and personal parenting which dimensions increase students' feeling of competence and motivate parents to become involved. Then Bronfenbrenner (1994) emphasizes parental involvement in child education using the overlapping spheres of influence between the home, school and the community contexts as highly influencing children's cognition. Finally, Becker and Epstein (1982) provide a variety of techniques for involving parents in their children's education. In a survey of 3700 first, third and fifth grade teachers, Becker and Epstein (1982) found out these techniques could be grouped into five broad categories. (a) reading activities, (b) learning through discussion, although these authors do not detail practical mechanisms for effecting reading and learning through discussions (c) They also note supervision and review of homework, (d) rewards and punishments, and (e) fostering parental tutoring skills. But Keith, Reimers, Fehrmann, Potterbuam and Aubey (1986) define parent involvement in terms of perceived expectations for performance, verbal encouragement or interactions regarding homework, direct reinforcement for academic improvement, and general academic guidance or support. Finally, Bempechat and Ginsburg (1989) developed the Educational Socialization Scale (ESS) to tap academic and cognitive socialization practices, indicate parents frequent and high control at and after school, close supervision as well as high support for academic activities.

In summary, there are volumes of debates on parent involvement in child education and its impact on academic performance variables. However, much of these debates are from western bred researches. Having noted that there multiple divergencies in study outcomes because of the geographical distance hypothesis, it is therefore not prudent to rely wholly on these studies which we know are from a different regional setting. The results for these studies are rather 
not generalizable to a developing world context like that of Uganda. The same literature espouses that differences in study findings from a several scholarly works is partly due to differences in variables examined by different scholars. Often these variables are also location specific necessitating a study on Uganda with quite applicable variables.

\section{Design and Sample}

\section{RESEARCH TOOLS AND METHODS}

Because the literature review indicates that variations in geographical locations explain variations in study findings, this study adopts the comparative research design to compare the influence of parent involvement in child education composites on academic performance across a set of denominational secondary schools in Tororo district. The researchers use a set of denominational schools of Catholic, Anglican, Muslim (Religious) and Government (Secular) founding bodies. The selection of these three major denominational schools out of several is mainly because these three religious denominations pioneered western formal education in Uganda (Ssekamwa, 2001). The change in the education policy between 1922 and 1962 did much to bring these denominational philosophies into the realm of Ugandan Education (Kasibante \& Kiwanuka, 2001). Therefore, it is important to trace and examine the progress of schools under traditional founding bodies. The researchers further adopted quantitative research approaches, which involved use of the structured questionnaire, descriptive and inferential statistics. Tororo district was sampled in Eastern Uganda for this study because for the last three consecutive years, eastern Uganda has had the poorest performance in both ordinary and advanced level national examinations (Uganda National Examinations Board Results, 2015-2018).

The study was conducted on clusters of eight denominational schools with a total sample of 360 student respondents, where by 45 students were randomly picked from each denominational school. The sample is made up of (198) 55\% males and (162) 45\% females.

\section{Development of the Questionnaire}

The researchers developed a structured questionnaire. During instrumentation, researchers adopted and modified Henderson and Mapp's (2017) Parent Involvement Guide (PIG), building from the sub-variables of the conceptual framework (Figure 1). The PIG guide offers process measures. It has Process Measure One with 30-items categorized into parent involvement at home with 19-items. It also has Process Measure Two which looks at 11-items designated as Parent Involvement at School. The PIG guide was validated using Confirmatory Factor Analysis $(\mathrm{CFA})^{1}$, with a three-Likert response rating ranging from 1= Yes"; $2=$ "No"; $3=$ "I don't know" (See Appendix 1). Results of the CFA validation were 0.78 , which is 78 percent. This makes the instrument items valid and reliable. Structured questionnaires were mailed to the students through the head teachers who acted as the research gate-keepers.

\section{The Checklist}

The researchers developed a checklist (See Appendix 2) mainly to tap students' academic grades as a unit of analysis for academic performance. They used students' average grades from in-class tests or exercises, end-of-term examinations, mid-term examinations, beginning of term examinations, and end-of year examinations. Finally, they used student grades from the Uganda National Examinations Board (UNEB) as a yardstick to measure children's academic achievement on completion of Ordinary Level (Naluwemba, Sekiwu \& Kaggwa, 2015).

${ }^{1}$ With CFA, only items with higher Eigen Values were picked as relevant to the study and outliers were excluded. 


\section{Data Analysis Methods}

Data was analyzed quantitatively where by objective one "to compare students' academic performance across various denominational schools and varied parents/guardians' socioeconomic status" was analyzed using a one-way analysis of variance (ANOVA) to show whether there is a difference in academic performance across varying mean groups. Then objective two "to assess the level of parent involvement in child education at home and in school" was analyzed using descriptive statistics of the mean and standard deviations, whereby a high mean value was interpreted as high parent involvement in child education.

Finally, objective three "to examine the relationship between parent involvement in child education and students' academic performance bearing in mind parents' socio-economic status" was analyzed using linear regression analyses based on the Bivariate linear model of the sort:

$$
f(Y)=a_{0}+\sum_{n=1}^{\infty}(\beta X i)+e
$$

Where Y=Student Academic Performance; $a_{0}=$ the constant; $X i=$ the parent involvement in child education composites. Then $\sum_{n=1}^{\infty}(X i)$ is the summation of the values obtained from the independent variables. The $\beta$ represents the coefficients of determination of $X_{i .}$ The independent variable $(X i)$ is categorised into Parent involvement at home $\left(\mathrm{x}_{1}\right)$ and parent involvement at school $\left(\mathrm{x}_{2}\right)$. Finally, e denotes the residual values consisting of the study control variables such as parents' socio-economic status. This model fit was the basis for computing regression values.

\section{Ethics}

In compliance with the standard practice in Uganda, the ethical approval to use the students (or human subjects) for the study was sought and obtained from the Ministry of Education and Sports, National Council for Science and Technology (NCSTE), the respective gate-keepers such as the head teachers who acted as the students' surrogate parents, and the parents themselves to give consent for involving their children in the study. A student respondent was free to leave the interview in case he or she found it unethical to continue being interviewed and names of respondents were kept confidential.

\section{RESULTS}

The results are presented according to the three objectives.

\section{objective 1: To compare students' academic performance across eight denominational Schools.}

This objective was analyzed using the one-way analysis of variance (ANOVA) to test how student academic performance differs according to various sample means (denominational schools). The result of data analysis is presented in Table 1.

Table 1: Descriptives for mean comparison of students' academic performance across eight denominational Schools

\begin{tabular}{lccccc} 
Denominational Schools & $\mathbf{N}$ & Mean & Std. Deviation & Minimum & Maximum \\
\hline Two Catholic Schools & $90^{* * *}$ & 22.18 & 10.338 & 8 & 48 \\
Two Government Schools & 90 & 22.07 & 10.465 & 8 & 48 \\
Two Anglican Schools & 90 & 22.11 & 10.143 & 10 & 48 \\
Two Moslem Schools & 90 & 21.24 & 8.443 & 8 & 39 \\
\hline
\end{tabular}

${ }^{* * *} 45$ student respondents picked from each school to make 90 
The Descriptives table 1 indicates that Moslem Schools perform lower $(\mu=21.24)$ than the other denominational schools, while Catholic Schools perform better $(\mu=22.18)$ than the other three denominational schools, followed by Anglican Schools $(\mu=22.11)$ and government schools $(\mu=22.07)$, with students' scores ranging from 8 (Minimum) to 48 (Maximum) aggregates. The standard deviation for Moslem Schools is 8.443 times less than the other denominational schools, indicating that student performance within the sampled Moslem schools seems to exhibit stiff competition among students in Moslem schools.

On the other hand, the standard deviations for Catholic (10.338), government (10.465), and Anglican (10.143) schools being larger than that of Moslem Schools (8.443), implying that student performance in Catholic, government and Anglican schools sampled for this study tends to vary extensively, which shows that there is performance variation among learners in these schools than the Moslem schools.

Table 2: ANOVA of student academic performance in Denominational Schools

\begin{tabular}{lccccc}
\hline Category & $\begin{array}{c}\text { Sum of } \\
\text { Squares }\end{array}$ & df & Mean Square & F & Sig. \\
\hline 1. Between Groups & 26.067 & 3 & 8.689 & 0.089 & 0.966 \\
Within Groups & 17184.133 & 176 & 97.637 & & \\
\hline Total & $\mathbf{1 7 2 1 0 . 2 0 0}$ & $\mathbf{1 7 9}$ & & & \\
\cline { 1 - 3 }
\end{tabular}

In the case of ANOVA, this test is reported in table 2. The F-Statistic (0.089) is far less than the level of significance (0.966) confirming that there are significant differences in student performance across the eight denominational schools at 3 degrees of freedom.

\section{Objective 2: To assess the level of parent involvement in child education at home and in school.}

The result of data analysis is presented in table 3 where the level of parent involvement in child education is higher in homes $(\mu=24.79)$ than at school $(\mu=15.68)$ from 360 student respondents. However, experiences of parent involvement in child education tend to differ more at home $(S D=6.009)$ than for parent involvement experiences at school $(S D=3.723)$.

Table 3: Descriptive Statistics assessing level of parent involvement in child education

\begin{tabular}{lccc}
\hline Variable & N & Mean & Std. Deviation \\
\hline Parent involvement in child education at Home & 360 & 24.79 & 6.009 \\
Parent involvement in child education at School & 360 & 15.68 & 3.723 \\
Valid N (listwise) & $\mathbf{3 6 0}$ & & \\
\hline
\end{tabular}

We computed for factors accounting for higher parent involvement in child education at home than at school using the Principal Component Analysis (PCA) method to extract these principal factors (Table 4). 
Table 4: Parent Involvement Home-based Factors that explain high Academic Performance Extracted Using PCA method

Variables/Items

Giving Academic Tips

Involvement in Teaching

Financing Educational Needs

Limit Privileges when obtain low

grades

Parent Encouragement of child

Career Guidance
Extracted Components ${ }^{a}$

Participation Rewards Monitoring Supportive

Counsel

0.992

0.962

0.971

0.903

0.900

0.958

$\begin{array}{ll}\text { Giving tokens in case of high grades } & 0.930 \\ \text { Paying School fees } & 0.921 \\ \text { Constructive criticisms } & 0.919\end{array}$

Monitor child homework

Guide choice of disciplines

0.774

Engagement in academic conversations and debates

Supporting children in their academic

journey

Counsel child in case obtained bad

grades

$\%$ of Variance

39.920

19.352

15.650

0.737

Cumulative

0.804

$\mathbf{8 6 . 2 6 7 \%}$

11.345

From table 4, parent involvement in child education at home explains academic performance by 86.267 percent compared to their involvement at school. In this way, parents' participation (39.920 percent) in child education is through giving academic tips (0.992), teaching (0.962), financing educational needs (0.971), limiting privileges when children obtain low grades (0.903), encouragement of the child (0.900) and career guidance (0.958). Parents also reward performance (19.352 percent) through giving tokens to good performers (0.930), paying school fees $(0.921)$ and offering constructive criticisms to promote positive performance (0.919). Again, parents monitor (15.650 percent) children through homework (0.774), guiding choice of discipline of study (0.804) and engagement in academic conversations and debates (0.804). Finally, they give supportive counsel (11.345 percent) that includes supporting children in their academic journey (0.737) as well as counselling children in case they obtain bad grades (0.737).

\section{Objective 3: Relationship between parent involvement in child education and students' academic performance with parents' socio-economic status as control variable.}

We analyzed the strength of the linear relationship between parent involvement in child education and students' academic performance using Pearson Correlation Coefficient. Coefficients of Table 5 indicate a positive relationship between parent involvement in child education and students' academic performance $(\mathrm{R}=0.216)$ and the relationship is statistically significant ( $\mathrm{t}=-1.489 ; \mathrm{p}=0.000)$. We further sought to establish the line that best describes the relationship between parent involvement in child education and students' academic 
performance by conducting a linear regression analysis. However, the slope or B column (Table 5) indicates that the coefficient of determination $(\beta)$ for parent Involvement in child education is 0.057 . This means that for every one-percentage increase in parent involvement in child education, there is a predicted increase in students' academic performance of nearly 0.06 percent (0.057) in each denominational school.

For how well the statistical model explains variation in students' academic performance (dependent variable), Adjusted R-square statistic shows that 0.6 percent of variation in students' academic performance can be attributed to two variables-parent involvement in child education and their socio-economic status, which is highly insignificant because of their low explanatory power in the model, and the remaining 99.4 percent can be explained by other factors excluded from the model.

Table 5: Coefficients ${ }^{\mathrm{a}}$

\begin{tabular}{|c|c|c|c|c|c|c|}
\hline & $\mathrm{R}^{2}=0.017$ & Adj $R^{2}=0.00$ & & & & \\
\hline & & $\begin{array}{r}\text { Unstan } \\
\text { Coef } \\
\end{array}$ & $\begin{array}{l}\text { rdized } \\
\text { ents } \\
\end{array}$ & $\begin{array}{c}\text { Standardized } \\
\text { Coefficients }\end{array}$ & & \\
\hline & & $\mathbf{B}$ & Std. Error & Beta & $\mathbf{t}$ & Sig. \\
\hline 1 & (Constant) & 20.322 & 1.552 & & 13.095 & 0.000 \\
\hline & Parent Involvement in Child Education & 0.057 & 0.038 & 0.131 & -1.489 & 0.000 \\
\hline & Parents' Socio-Economic Status & 1.073E-7 & 0.000 & 0.096 & 1.252 & 0.000 \\
\hline
\end{tabular}

Using linear regression coefficients and the Model fit, we sought to predict the students' academic performance. The Model fit is $f(\boldsymbol{Y})=\boldsymbol{a}_{\mathbf{0}}+\sum_{\boldsymbol{n}=\mathbf{1}}^{\infty}(\boldsymbol{\beta} \boldsymbol{X} \boldsymbol{i})+\mathbf{e}$ (Section 4.7), where $\left(a_{0}=20.322\right)$, ( $\left.\mathrm{B}(\beta)=0.057 / 0.06\right)$. When parent involvement in child education at home is 24.79 (Table 3), students' academic performance (Y) is 21.809 percent, and where parent involvement in child education at school is 15.68 (Table 3), students' academic performance (Y) is 21.262 (See Table 6).

Table 6: Predicting Students' Academic Performance Using Linear Regression Coefficients

\begin{tabular}{ccccc}
\hline $\begin{array}{c}\text { Constant } \\
\left(\boldsymbol{a}_{\mathbf{0}}\right)\end{array}$ & Beta $(\boldsymbol{\beta})$ & $\begin{array}{c}\text { Independent } \\
\text { variables }(\boldsymbol{X} \boldsymbol{i})\end{array}$ & $\begin{array}{c}\text { Predicted Dependent } \\
\text { variable }(\boldsymbol{Y})\end{array}$ & Approximate \% \\
\hline 20.322 & $0.06(0.057)$ & $15.68^{* * *}$ & 21.262 & 21 percent \\
20.322 & $0.06(0.057)$ & $24.79^{* *}$ & 21.809 & 22 percent \\
20.322 & $0.06(0.057)$ & 40 & 22.722 & 23 percent \\
20.322 & $0.06(0.057)$ & 60 & 23.922 & 24 percent \\
20.322 & $0.06(0.057)$ & 80 & 25.122 & 25 percent \\
20.322 & $0.06(0.057)$ & 100 & 26.322 & 26 percent \\
20.322 & $0.06(0.057)$ & 110 & 26.922 & 28 percent \\
20.322 & $0.06(0.057)$ & 120 & 27.522 & 28 percent \\
20.322 & $0.06(0.057)$ & 130 & 28.122 & 29 percent \\
20.322 & $0.06(0.057)$ & 140 & 28.722 & \\
\hline
\end{tabular}

${ }^{* *}$ Level of parent involvement at home

${ }^{* * *}$ Level of parent involvement at school

As a matter of education policy, from results in table 6, if school managers increase parent involvement in child education by 100 percent (from 40 to 140), this would increase students' academic performance by only 6 percent (Table 6) which is equivalent to the coefficient of determination $($ Beta $=\beta)$. 


\section{Parent involvement in child education at $140 \% \quad=29$ percent \\ Parent involvement in child education at $40 \%=23$ percent \\ Percentage increase in Parent Involvement $(\beta) \quad=6$ percent}

This implies that education policy makers need to ensure that they encourage parents to involve in child education in order to increase academic performance. They need also to employ other factors that influence students' academic performance other than parent involvement in child education and parents' socio-economic status.

\section{DISCUSSION}

The data was analyzed according to three objectives. This study found a positive relationship between parent involvement in child education and students' academic performance $(\mathrm{R}=0.216)$ in eight denominational schools, and the relationship is statistically significant $(\mathrm{t}=-$ 1.489; $\mathrm{p}=0.000$ ). This finding fully supports the study of Fajoju, Oyaziwo, Aluede and Ojugo (2016) who found that parental involvement significantly influences achievement in English language as a core subject, although their study was conducted in primary schools not secondary schools. However, the parent involvement in child education has a low explanatory power (Adjusted $\mathrm{R}=0.006$ ). The remaining 99.4 percent can be explained by other factors excluded from the model such as quality of teachers, quality of academic infrastructure, quality of students among others. One may not be too surprised that parent involvement in child education is generally low because even the Twaweza (2014) study noted this. There is need for education policy makers, teachers and researchers to encourage parents to get involved in child education, as well as bringing on board other factors that influence students' academic performance.

This study also found that there are significant differences in students' academic performance across the eight denominational schools as indicated by ANOVA results. For example, Moslem schools perform lower than the other denominational schools, although there is stiff competition among students within the Moslem school yet performance within other denominational schools varies extensively. This finding is similar to Muwagga, Mugimu, Ssenkusu and Wafula (2016) who argue that different denominational education institutions tend to exhibit different value-orientations and identity which impact on school performance differently. Because Moslem schools have slightly different values from other denominational schools, they ought to have variations in performance compared to other denominational schools. Similarly, Mugagga and Genza (2016) argue that catholic schools tend to have high academic performance because they exhibit a strict catholic ethos which is based on discipline and evangelism.

The study also found that parent involvement in child education is higher at home than in the school. Bempechat (1992) attributes this finding to the fact that, for the increasing demands of the White-Collar job, parents do not have enough time to visit their children in school to check on their academic progress than they would do this at home. Therefore, parents have more time for their child's education at home than at school.

\section{CONCLUSION AND IMPLICATIONS}

This study indicates that parent involvement in child education positively influences students' academic performance with parents' socio-economic status as the control variable, although parent involvement in child education has a low contribution to students' academic performance. For example, a 100 percent increase in parent involvement in child education would increase students' academic performance by only 6 percent. The study concludes that 
other factors that influence students' academic performance by 99.4 percent ought to be identified by education policy makers. The study further indicates that students' academic performance varies among different denominational schools, and that there is low parent involvement in child education in Moslem schools where academic performance is lower, and high parent involvement in child education in Catholic, Anglican and government schools where academic performance is higher. Again, the study shows that parent involvement in child education is higher in the home than at school, implying that parent involvement in child education in the home is more in Catholic schools where academic performance is higher. On the other hand, parent involvement in child education at school is more in Moslem schools where academic performance is lower. As a matter of policy, there is need to encourage parents to get involved in child education, and the more they get involved the more students' academic performance is predicted to increase. We also encourage various denominational schools to improve their values-orientations to focus on increasing students' academic performance, because denominational school management is highly dependent on the institutional values or philosophy in place

\section{LIMITATIONS OF THE STUDY}

The study was based on only eight denominational schools, a sample that is not representative of all denominational schools in Uganda. This makes the generalizability of study findings difficult. However, the sample was selected randomly which tries to make it more representative. There is need to conduct a similar study but with multiple independent variables that influence academic performance.

\section{DECLARATION OF CONFLICT OF INTEREST}

The authors declared no potential conflicts of interest with respect to the research, authorship, and/or publication of this article.

\section{FUNDING}

The authors wish to acknowledge financial support for the research, authorship, and/or publication of this article from Kabale University's directorate of Research.

\section{References}

Ahuja, R. (2005). Society in India concepts, Theories and Recent Trends. New Delhi: p.215

Alexander, K. L., Entwisle, D. R., \& Horsey, C. S. (1997). From first grade forward: Early foundations of high school dropout. Sociology of Education, Vol. 70, 87-107.

Allardice, M., \& Blicharski, J. (2000). Tracking Students' Progression: Learning their Lessons. Journal of Widening Participation and Lifelong Learning, Vol. 2 (3): pps.32-37. doi:10.1037/0022-0663.100.2.235.

Appleton, J., Christenson, S.L., Kim, D., \& Reschly, A. (2006). Measuring cognitive and psychological engagement: Validation of the Student Engagement Instrument. Journal of School Psychology, Vol.44, 427-445.

Appleton, J.J. (2012). Systems consultation: Developing the assessment-to-intervention link with the Student Engagement Instrument. In S. L. Christenson, A. L. Reschly, and C. Wylie (Eds.), Handbook of Research on Student Engagement. (pp. 725-741). New York: Springer.

Arnstein, Sherry R. (1969). A ladder of citizen participation. Journal of the American Institute of Planners, 35 (4) (July), 216- 224.

Becker, H., \& Epstein, J. (1982). Parent Involvement: A survey of teachers' practices. The elementary school Journal, Vol. 83, pps. 85-102.

Bempechat, J., \& Ginsburg, H. (1989). Underachievement and educational disadvantage: The home and school experience of at-risk youth. Urban Diversity Series, No. 99. New York: ERIC Clearinghouse on Urban Education, Teachers College, Columbia University.

Bempechat, Janine (1992). The role of parent involvement in children's academic achievement. The School Community Journal, Vol. 2 (2), pps. 31-41. 
Benner, Aprile D., \& Mistry, Rashmita S. (2007). Congruence of mother and teacher educational expectations and low-income youth's academic competence. Journal of Educational Psychology, Vol. 99(1), 140-153.

Breen, R., \& Jonsson, J.O. (2005). Inequality of Opportunity in Comparative Perspective: Recent Research on Educational Attainment and Social Mobility. Annual Review of Sociology Vol. 31 (2), pps. 223-243. doi: 10.1146/annurev.soc.31.041304.122232

Carter, C., Reschly, A. L., Lovelace, M. D., Appleton, J. J., \& Thompson, D. (2012). Measuring student engagement among elementary students: Pilot of the Elementary Student Engagement Instrument. School Psychology Quarterly, 27, 61-73.

Christenson, S., \& Reschly, A. (2010). Handbook of School-Family Partnerships. New York: Taylor \& Francis.

Clarke-Steward, A. (1983). Exploring the assumptions of parent education. In R. Haskins \& D. Adams (Eds.), Parent education and public policy, Norwood, NJ: Ablex.

Coleman, J.E., Campbell, C., Hobson, J., McPartland, A., Mood, F. W., \& York, R. (1966). Equality of Educational opportunity. Washington, D.C: US. Government Printing Office.

Davis-Kean, Pamela E. \& Sexton, Holly R. (2009). Race differences in parental influences on child achievement: Multiple pathways to success. Merrill-Palmer Quarterly 55(3), pps.285-318.

Desimone, L. (1999). Linking parent involvement with student achievement: Do race and income matter? The Journal of Educational Research, Vol. 93(1), pps.11-30.

Dubas, J.S., \& Gerris, J.R.M. (2002). Longitudinal changes in the time parents spend in activities with their adolescent children as a function of child age, pubertal status and gender. Journal of Family Psychology, Vol.16 (4), pps. $415-427$

Eccles, J. (1983). Expectancies, values, and academic behaviours. In J. Spence (Eds.), Achievement and Achievement motives: Psychological and social approaches. New York: Freeman.

Eccles, J.S. \& Harold, R.D. (1996). Family involvement in children's and adolescents' schooling. In A Booth \& J.F. Dunn (Eds.), Family-School links: How do they affect educational outcomes? (pps. 3-34). Mahwah, NJ: Erlbaum.

Eccles, J.S., \& Harold, R.D. (2004). Family involvement in children's and adolescent's schooling. In: A., Booth \& J.F. Dunn (Eds.,), Family School Links. Lawrence Erlbaum Associates; Mahwah, NJ: pp. 3-34.

Elbaum, B. (2014). Challenges in interpreting accountability results for schools' facilitation of parent involvement under IDEA. Journal of Disability Policy Studies, 24(4), 206-217.

Epstein, J. (1986). Parents' reactions to teacher practices of parent involvement. The Elementary Scho4ol Journal, Vol. 56, 277-294.

Epstein, J. (1988). How do we improve programmes for parental involvement? Educational Horizons, Vol. 66, pps. 58-59.

Epstein, J. (2002). School, family, and community partnerships: Preparing educators and improving schools. Boulder, CO: West-view Press.

Epstein, J. L. \& Saunders, M.G. (2002). Family, school, and community partnerships. In M.H. Fredricks, Jennifer, Blumenfeld, Phyllis C., Paris, Alison H. (2009). School engagement: Potential of the concept, state of the evidence. Review of Educational Research, Vol. 74(1), pps.59-109.

Epstein, J. L. (2001). School, Family, and Community Partnerships: Preparing Educators and Improving Schools. Boulder, CO: West-view.

Epstein, J. L., \& Jansorn, N. R. (2004). School, family, and community partnerships link the plan. Education Digest, Vol. 69 (6), pps.19-23.

Epstein, J.L. (1995). School/family/community partnerships. Phi Delta Kappan, 76, 701- 712.

Epstein, J.L., Sanders, M.G., Simon, B.S., Salinas, K.C., Jansorn, N.R. \& Voorhis, F.L. (2002). School, Family and Community Partnerships: Your Handbook for Action ( $2^{\text {nd }}$ edition). Corwin, Thousand Oaks, California

Fajoju, S.A., Oyaziwo, Aluede \& Ojugo, A.I (2016). Parental Involvement as correlates of academic achievement of primary school pupils in Edo State, Nigeria. Research in Education. Vol. 95 (1), pp. 33-43.

Sagepub.co.uk/journalsPermissions.nav. DOI:10.7227/RIE.0023

Fan, X. (2001). Parental involvement and students' academic achievement: A growth modelling analysis. Journal of Experimental Education, Vol.70(1), pps.27-61. 
Fehrmann, P. G., Keith, T. Z., \& Reimers, T. M. (1987). Home influence on school learning: Direct and indirect effects of parental involvement on high school grades. The Journal of Educational Research, Vol. 80(6), pps.330337.

Ferrara, M.M. (2009). Broadening the myopic vision of parental involvement. School Community Journal, Vol. 19(2), pps. 123-142.

Finn, J. D. (1993). School engagement and students at risk. Washington, DC: National Centre for Education Statistics.

Finn, J. D., Rock, D. A. (1997). Academic success among students at risk for school failure. Journal of Applied Psychology, Vol.82, pps.221-234.

Gibson, D.M. \& Jefferson, R.N. (2006). The effect of perceived parental involvement and the use of growth fostering relationships on self-concept in adolescents participating in gear-up. Adolescent, Vol. 41(161), pps. 111-125.

Gonzalez-Pienda, J. A., Nunez, J. C., Gonzalez-Pumariega, S., Alvarez, L., Roces, C., \& Garcia, M. (2002). A structural equation model of parental involvement, motivational and aptitudinal characteristics, and academic achievement. The Journal of Experimental Education, Vol.70(3), pps.257-287.

Grolnick, W.S., \& Slowiaczek, M.L. (1994). Parents' involvement in children's schooling: A Multidimensional Conceptualization and Motivation Model. Child Development, Vol. 65 (1), pps. 237-252.

Grolnick, Wendy S. \& Slowiaczek, Maria L. (1994). Parents' involvement in children's schooling: a multidimensional conceptualization and motivational model. Child Development, Vol.65, pps.237-252.

Hara, S.R. (1998). Parent Involvement: The key to improved student achievement. School Community Journal, Vol. 8 (2), pps. 9-19.

Henderson, A. (1987). The evidence continues to grow: Parent involvement improves student achievement. Columbia, MD: National Committee for Citizens in Education.

Henderson, A. (2009). The Evidence Continues to grow: Parent Involvement Improves Student Achievement: An Annotated Bibliography. Columbia, M.D: National Committee for Citizens.

Henderson, P., \& Mapp, N. (2017). Measuring the Effectiveness of Parent Engagement Initiatives. FAST: Families And Schools Together. Colorado Department of Education.

Hill, N.E. \& Craft, S.A. (2003). Parent-School involvement and school performance: Mediated pathways among socioeconomically comparable African-American and Euro-American Families. Journal of Educational Psychology, Vol. 95, pps. 74-83.

Hill, N.E. \& Taylor, Lorraine C. (2004). Parental school involvement and children's academic achievementpragmatics and issues. Current Directions in Psychological Science, Vol. 13(4), pps.161-164.

Hill, N.E. (2001). Parenting and academic socialization as they relate to school readiness: The role of ethnicity and family income. Journal of Educational Psychology, Vol. 93 (2), pps. 686-697.

Hill, N.E., \& Craft, S.A. (2003). Parent-school involvement and school performance: Mediated pathways among socioeconomically comparable African American and Euro-American families. Journal of Educational Psychology, Vol.96, pps.74-83.

Hill, N.E., \& Taylor, L. (2004). Parental School involvement and Children's Academic Achievement: Pragmatics and Issues. Current Directions in Psychology Science, Vol. 13(4), pps. 161-164.

Hughes, P. \& Black, A. (2002). The impact of various personal and social characteristics on volunteering. Australian Journal of Volunteering, Vol. 7(2), pps. 59-69.

Jeynes, H.W. (2007). The relationship between parental involvement and Urban Secondary School student academic achievement: A meta-Analysis. Urban Education, Vol. 42(1), pps.82-110.

Jeynes, W. (2006). Standardized tests and the true meaning of kindergarten and pre-school. Teachers' College Record, Vol. 108 (10), pps. 1937-1959.

Jeynes, W. (2010). The salience of the subtle aspects of parental involvement and encouraging that involvement: Implications for school-based programmes. Teachers College Record, Vol. 112 (3), pps. 747-774.

Jeynes, W. (2012). A Meta-Analysis of the Efficacy of Different types of parental involvement programs for Urban students. Urban Education. Vol. 47 (4), pps. 706-742

Jeynes, W. H. (2005). The effects of parental involvement on the academic achievement of African American youth. The Journal of Negro Education, 74(3), pps.260-274. 
Jeynes, W. H. (2009). The relationship between parental involvement and urban secondary school student academic achievement: A meta-analysis. Urban Education 42, pps.82-110.

Keith, T.T., Reimers, P., Fehrmann, S., Potterbuam, \& Aubey, L. (1986). Parent Involvement, homework, and TV time: Direct and indirect effects on high school achievement. Journal educational psychology, Vol. 78, 373-380.

Lareau, A. (1999). Assessing parent involvement in schooling: A critical analysis. In A. Booth \& J.F. Dunn (Eds.), Family-School links: How do they affect educational outcomes? (pp. 57-64). Mahwah, NJ: Erlbaum.

Mabovula, N.N. (2008). A philosophical exploration of democratic participation in school governance in selected South African black schools in the Eastern Cape Province. Unpublished Doctoral Thesis. Stellenbosch: Stellenbosch University.

Marcon, RA. (1999). Positive relationships between parent school involvement and public school inner-city preschoolers' development and academic performance. School Psychology Review. Vol.28, pps.395-412.

Marks, H. M. (2000). Student engagement in instructional activity: Patterns in the elementary, middle, and high school years. American Educational Research Journal, Vol.37, pps.153-184.

Mau, W. (1997). Parental influences on the high school students' academic achievement: A comparison of Asian immigrants, Asian Americans, and White Americans. Psychology in the Schools, Vol. 34 (3), pps. 267-277.

McGhee, J. \& Waterhouse, L.U. (2002). Family support and the Scottish children's hearing system. Child \& Family Social Work, Vol. 7, pps. 273-284.

McKenzie, B. (2008). Reconsidering the effects of bonding social capital: A closer look at black civil society institutions in America. Political Behaviour, Vol. 30 (1), pps. 25-45.

McNeal, R.B. (1999). Parental involvement as social capital: Differential effectiveness on science achievement, truancy and dropping out. Social forces, Vol. 78, pps. 117-144.

Moles, O.C. (2002). Synthesis of recent research on parent participation in children's education. Educational Leadership, Vol. 40, pps. 44-47.

Mugagga, A.M., Sekiwu, D., Kiggundu-Musoke, M. (2016). The Philosophy of Global Citizenship Education Agenda (GCEA) and the Educators' Competence to implement it: The Case for Ugandan Secondary Schools. Journal of Education Review, Vol.9 (1), pps. 125-144.

Muwagga, A.M., Mugimu, C., Ssenkusu Mpiso, P. \& Wafula, W.S. (2016). A discourse on the values transmitted in Universities in Uganda. Makerere Journal for Higher Education (MAJOHE), Vol. 8(2), pp.91-106.

Naluwemba, Frances. Sekiwu, Denis \& Victoria Tamale Kaggwa (2015). School Heads' Leadership Traits and Learners' Academic Attainment in Uganda's High Schools. Donnish Journal of Educational Research and Reviews Vol 2(3) pp. 039-047 April, 2015. http://www.donnishjournals.org/djerr

Nkata, J.L. (2003). Pertinent Issues in Management of Educational Institutions in the Developing World. Masah Publishers: Kampala

Patil, N (2016). Role of Education in Social Change. International Educational E-Journal, Vol.1 (2), pps.105-110.

Pelco, L.E., Jacobson, L., Ries, R.R., \& Melka, S. (2000). Perspectives and practices in family-school partnerships: A national survey of school psychologists. School Psychology Review, Vol.29, pps.235-250.

Prew, M. (2009). Community involvement in school development: Modifying school improvement concepts to the needs of South African township schools. Educational Management Administration \& Leadership, Vol.37, pps.824846.

Prior, J., \& Gerard, M.R. (2007). Family involvement in Early child hood education: Research into Practice. New York: Thomson.

Rieber, R.W., \& Robinson, D.K. (Eds), (2004). The Essential Vygotsky. New York: Kluwer Academic/ Plenum Publishers.

Rogoff, B., \& Gardner, W. (1984). Adult guidance of everyday cognition. In everyday cognition: Its development in social context. In B. Rogoff \& J. Lave (Eds.). Cambridge: Harvard University Press.

Sekiwu, D. \& Botha (Nonnie), M.M. (2014). Education as a public good: Justification and Avenues of values integration into Management of Ugandan school discipline. Global Educational Research Journal, Vol. 2(10), pps.195-208.

Shanham, T., \& Walberg, H. (1985). Productive influences on high school student achievement. Journal of Educational Research, Vol. 78 (6), pps. 357-363. 
Sheldon, S. B., \& Epstein, J.L. (2002). Improving student behaviour and school discipline with family and community involvement. Education and Urban Society, Vol.35, pps.4-26.

Sithole, S. (1998). Parent-Teacher-Student Associations (PTSAs): Present State and Future Prospects, (1 st $^{\text {edition}) . ~}$ (In Education Policy Unit, NATAL), Democratic Governance of Public Schooling in South Africa, A record of research and advocacy from the Education Policy Unit. Natal, Durban. EPU NATAL, 39-49.

Smith, A.G., \& Liebenberg, L. (2003). Understanding the dynamics of parent involvement in schooling within the poverty context. South African Journal of Education, Vol.23, pps.1-5.

Spera, C. (2006). Adolescents' perceptions of parental goals, practices, and styles in relation to their motivation and achievement. The Journal of Early Adolescence Vol.26, pps.456-490.

Steinberg, L., Lamborn, S. D., Dornbusch, S. M., \& Darling, N. (1992). Impact of parenting practices on adolescent achievement: Authoritative parenting, school involvement, and encouragement to succeed. Child Development, Vol.63(5), pps.1266-1281.

Sui-Chu, E. H., \& Willms, J. D. (1996). Effects of parental involvement on eighth-grade achievement. Sociology of Education, 69(2), pps.126-141.

Sweet, A.S., \& Karen, G.M. (2003). Data Analysis with SPSS: A first course in applied Statistics. Boston: Pearson Education, Inc.

Sy, S.R. (2006). Rethinking parental involvement during the transition to the first grade: A focus on AsianAmerican families. School Community Journal, Vol. 16 (1), pps. 107-125.

Tamara Thiele, Alexander Singleton, Daniel Pope \& Debbi Stanistreet. (2016). Predicting students' academic performance based on school and socio-demographic characteristics. Studies in Higher Education, Vol. 41 (8), pps.129-338

Texas Educational Agency (1999-2000). Texas Student Assessment Program Technical Digest for the academic year 1999-2000. NCS Pearson, Harcourt Educational Measurement, Measurement Incorporated, and Data Beta Inc.

Twaweza Monitoring Series (2014). Brief No.4. www.twaweza.org.

Voelkl, K. E. (1997). Identification with school. American Journal of Education, 105, pps.204-319.

Walberg, H., Bole, R. \& Waxman, H. (1980). School-Based family socialization and reading achievement in the inner-city. Psychology in the Schools, Vol. 17, pps. 509-514.

Williams, Patricia (2015). How do we build effective parent-school partnerships in inclusive schools? Inclusive Schools Network. www.inclusiveschools.org 